\title{
Traditional Medicinal Plants of Azerbaijan Province of Iran
}

\author{
Elnaz Latifian, Şahane Funda Arslanoğlu \\ Department of Field Crops, Faculty of Agriculture, Ondokuz Mayis University, Samsun, Turkey \\ Email: eli.latifian@gmail.com, farslanoglu@omu.edu.tr
}

How to cite this paper: Latifian, E. and Arslanoğlu, Ş.F. (2018) Traditional Medicinal Plants of Azerbaijan Province of Iran. Agricultural Sciences, 9, 157-170. https://doi.org/10.4236/as.2018.91012

Received: August 2, 2017

Accepted: January 28, 2018

Published: January 31, 2018

Copyright $\odot 2018$ by authors and Scientific Research Publishing Inc. This work is licensed under the Creative Commons Attribution-NonCommercial International License (CC BY-NC 4.0). http://creativecommons.org/licenses/by-nc/4.0/ (c) (i) \&) Open Access

\begin{abstract}
Aromatic herbs and spices are enormous and sustainable resource of natural compounds with various useful features in Iran. They have a variety of applications, especially in the treatment of disease and in order to create a pleasant scent and smell of food have been used since ancient times. Today, some of these plants are commercially grown and used in a variety of production of components. Our presentation is a study of the medicinal herbs of Eastern Azerbaijan. The province of Azerbaijan consists of two eastern and western parts. East Azerbaijan settles in the north-west of Iran. Eastern Azerbaijan has a cool and dry climate due to its mountainous region. There are approximately 1,300 species and 510 species of plants in Eastern Azer-baijan. These species have the most healing properties. In Eastern Azerbaijan regions, medicinal plants are usually collected by locals from mountains and meadows. Eastern Azerbaijan medicinal plants are not scientifically well known, but are traditionally used in rural areas. Usually used medicinal herbs in the area belong to Lamiaceae, Asteraceae, Rosaceae, Urticaceae, Apiaceae and Grossulariacea family. Some of the plants are Artemisia absinthium L, Sambucus nigra, Thymus Kotschyanus, Nasturtium officinale, Achillea millefolium L., Stachys schtschegleevi, Mentha longifolia L., Ecballium elaterium L., Leonurus cardiaca L., Cornus mas L., Rhus coriaria L., Salvia sclarea L., Hippophaer hamnoides L., Marrubium vulgare, Tanacetum balsamita L., Trifolium pratense L., Ziziphora clinopodioides Lam., Echium vulgare L. The purpose of the research is to introduce the method of use of medicinal plants in Eastern Azerbaijan.
\end{abstract}

\section{Keywords}

Herbs, East Azerbaijan, Methods of Use, Leonurus cardiaca, Hippophae rhamnoides 


\section{Introduction}

Iran is the 18th largest country of the world with an area of $1.648 .195 \mathrm{~km}^{2}$. It is surrounded by Armenia $(35 \mathrm{~km} / 22 \mathrm{mi}$ ) and Azerbaijan in the northwest (432 $\mathrm{km} / 268 \mathrm{mi}$ ); Caspian Sea in the north; Turkmenistan in the north east (992 $\mathrm{km} / 616 \mathrm{mi})$; Pakistan $(909 \mathrm{~km} / 565 \mathrm{mi})$ in the east, Afghanistan $(936 \mathrm{~km} / 582 \mathrm{mi})$ in the west and Turkey $(499 \mathrm{~km} / 310 \mathrm{mi})$ and Iraq $(1.458 \mathrm{~km})$ in the west and finally to the Gulf of Basra and Oman Gulf in the south [1].

Azerbaijan, located on the north-west of Iran, is composed of Eastern Azerbaijan (Tabriz), West Azerbaijan (Urumia), Erdebil, Hamedan, Kazvin and Zencan provinces. East Azerbaijan has a population of 3.603.456 and an area of $47.830 \mathrm{~km}^{2}$. The largest and oldest province of the region in terms of cultural, political and commercial is Tabriz. The majority of people are Azeri Turks and speak Turkish. The highest peak of eastern Azerbaijan is the Sahand Mountain at $3.722 \mathrm{~m}$ in the southern part of Tabriz, around Garmadüz (Ahar). This is followed by Karadağ, Bozkush and Kaflan Mountains. In general, Eastern Azerbaijan has a cool and dry climate due to its mountainous region. However, light winds from the south due to the Caspian Sea soften the air. Average temperature is $8.9^{\circ} \mathrm{C}$ in Tabriz. In winter the average temperature is between $-10^{\circ} \mathrm{C}$ and $-15^{\circ} \mathrm{C}$.

The use of herbal medicines began thousands of years ago and different treatment methods of the pharmaceutical industry are widely used in the countries. Due to the side effects of synthetic drugs, the herbal products and the desire for multilateral use of these plants in various pharmaceutical, food, and cosmetic industries increase. Considering the importance of this issue and the multi-purpose use of medicinal plants, a recent study was carried out on medicinal plants in the Azerbaijani region of Iran. Library studies and Internet resources indicate that there are more than 500 drug species in the East Azerbaijan province. $29 \%$ of these plants have a high nutritional value, and $54 \%$ of them are important in terms of sweetener and food [2].

There are approximately 1,300 species and 510 Family of plants in Eastern Azerbaijan. These species are used for medical aromatic purposes. These plant species are usually collected by local people from mountains, pastures and meadows and consumed for different purposes [3]. Scientific research on medicinal plants grown in Eastern Azerbaijan is quite insufficient. However, it is traditionally heavily used in rural areas.

\section{Methods}

In this study, some questions were asked to 37 people (local people and traditional druggist) in 2017 spring. All people whose local information was approved by local people were questioned. The sex of the 31 people was male and the rest were female. The age range of people was between 43 and 79 years old. 19 of these people were in the Tabriz city, but the rest, only local people familiar with 
the medicinal properties of medicinal plants, whose drug information was confirmed by local people. Six of them had a master's degree, eight had a bachelor's degree, and the rest had elementary degrees to diplomas.

The questions asked were:

1) What are the most important local medicinal herbs used?

2) The traditional use of medicinal plants?

3) What is the modern application of medicinal herbs?

Considering the answers to these questions, local healing plants were identified. As a result, the literature has been examined in terms of the correctness of treatment characteristics known to the person.

\section{Results}

Common wormwood who is known locally as Ovishon, which is known for its scientific name of Artemisia absinthium L. is a plant of Asteraceae. Beta-Thujone, p-Cymene and beta-Pinene, and consequently, 1,8-Cineole and Borneol is this plant medicinal plant [4]. It is a perennial herb and it is economically yielded in the first 5 years. The plant grows up to $120 \mathrm{~cm}$ in length and has leafy, greyish or whitish green colored leaves. It is a bitter plant. The origin is the temperate regions of Asia and Europe. The volatile oil is used by the food industry as a donor, in the case of deoxygenated water, it is consumed as tea. This is an insect repellent [4] [5].

1) Soothing nerves, lack of sleep, anemia relieve: 2 spoon in 1 cup boiling water for 30 minutes. It should drink before sleep.

2) Disruption in children: 2 spoon in 1 cup boiling water for $30 \mathrm{~min}$. It should drink before sleep.

3) Elimination of joint pain: 10 grams of borage mix with 1 cup of boiled water. It soothes joints pain.

4) Liver, Bile, Gastroenterology, Appetizer: 5 grams of it with 1 glass of beer every day, 2 times a day.

Infections and blisters: Dissolve 10 drops of water per day in 1 cup of cold water without being sweetened with any substance. This recipe must be repeated 3 to 4 days and 2 times throughout the day [6] [7].

\subsection{Elder}

Elder which is locally known as Agti, is known as scientific name Sambucus nigra L. Belong to Caprifoliaceae. Flavonoids (routine, quercetin, isoquercetin, astragalin), phenolic acid, vitamins $\mathrm{A}$ and $\mathrm{C}$ (in fruits) and anthocyanin can be named from the herbal compositions found in this plant [8]. Elderberry, 3 - 10 $\mathrm{m}$ sometimes bushes, sometimes in the form of a tree can be found. The leaves are usually composed of five pieces, two pairs and one single, each piece oval, with a very slightly curved edge with slightly raised green color and short stems. The flowers are quite small. It is white, yellowish or sometimes pale pink colored 
and sharp smelling, with broad umbrella or flower cluster. Elderberry, inner shell of roots are used for treatment purposes [8].

1) Treatment of rheumatism and joint pain, laxative and anti-constipation: herbal tea of dried leaves is used.

2) Eliminate the pain and heal hemorrhoids: Squeeze the fresh leaves of the herb, or make the ointment and put on painful Heathers.

3) Removing the itching of the body: The stem's skin boils it in oil, then it is cooled. This oil is applied to areas that itch.

4) Bone Wrap and Treatment of Bone Fractures: Use the herbal tea of the shrub root.

5) Greper, cold, breathernal diseases and greases: Herbal tea of dried flower is useful. Pour 100 grams of dried flower in a liter of hot water and boil for $10 \mathrm{mi}-$ nutes. They are also used to rinse the wounds.

6) Treatment of bronchitis and spinal cord: To prepare the decoction of this plant, $60 \mathrm{~g}$ of different parts of the plant are poured into a liter of water and slowly boil until the volume reaches half. Then it is smooth.

7) Treatment of tuberculosis, kidney and urinary tract diseases, removal of kidney stones, treatment of epilepsy disease: Incense of flowers [9].

\subsection{Yarrow}

Yarrow, which is known locally as Bomaderan (Achillea millefolium L.) is a plant of Asteraceae. Zovaleric acid, salicylic acid, asparagine sterols, flavonoids, bitters, tannins and kumarins can be named from the herbal compositions found in this plant. It is a plant of European and Asian origin. Feathered stalks are $20-90 \mathrm{~cm}$ high and open white flowers in summer. It likes dry land. The leaves are long and fragmented. The plant is grown on meadows, on field roads, on roadsides and on the edges of cereal fields. In the July-September period, flowers are cut down to two spots, suspended in bundles in shades and airy places. It dries well and hides in non-breathing cups. In East Azerbaijan, Yarrow is used as a stopping blooding and wound healing [10].

1) Fixing acute and chronic gastritis, treating stomach ulcers, bloating and tarting, reducing blood pressure, treating gallstone deficiencies, urinating and removing kidney stones, windbreaks, treating neurological diseases and fever: Boil its floral branches. Boil 10 to 20 grams of flowering branches or leaves in half a liter of water and taking one to three cups a day (It must be done in small quantities because it quickly deteriorates).

2) Antibacterial and anti-inflammatory properties: Essential oil.

3) Angina, sudden sting and numbness: Fresh juice of this plant.

4) Chest Pain: Pump.

5) Zakam treatment: Herbal tea and boil.

6) Laying blood and treating wound hemorrhage, relieving pain and preventing bleeding: Massaging the pain area with yarrow oil or burning it on the wound site. The effects of Achillea millefolium were known and used by the lo- 
cal people of Eastern Azerbaijan [11] [12].

\subsection{Liquorice}

Liquorice locally is known as Sus, with scientific name of Glycyrrhiza glabra L. is a plant found in Fabaceae. Glycyrrhizic acid is main herbal compositions found in this plant. It heals skin and lung diseases, liver and heart failure and has anti-inflammatory properties, antivirus, antimicrobials, antioxidants, anticancer and immune system can be strengthened by this plant [4]. It is one of the most important endemic plants in Iran. It is a perennial herbaceous family of legumes that can be growth up to $120-150 \mathrm{~cm}$. Their homeland is Russia and China. It has small, bluish, purple flowers. Leaves are $7-15 \mathrm{~cm}$ long. The root has a structure that reaches 1 meter [13].

1) Improve the wounds and blisters of the skin: Rinse with licorice tea.

2) Diuretic, cough coughing, stomach upset, dyspnea, dyspepsia, bloating of the abdomen: Herbal tea of licorice: Use 50 grams of rootless skin free of licorice, and Pour it in one liter boiling water and let it stand for 10 minutes. Or boiled licorice: GRIND 20 grams of licorice without skin, and pour in 100 grams of water and boil until it is left over two-thirds.

3) Remedies for ulcer and inflammation of the mouth: Sucking the lichen roots.

4) Strengthen the eyes and fix the headache: For this purpose use the following formula: Pour 2 grams of licorice root and mix with one gram of sugar and one gram of fennel, then soak it in water and eat it every day.

5) Hair leprosy treatment: Liquorice tea is used for hair care (usually for hair breaks). The use of this plant in ancient Azerbaijan proved with modern medicine [14] [15] [16].

\subsection{Watercress}

Watercress, which is known locally as Bulağ oti (Nasturtium officinale L.) is a plant of Brassicaceae. Glucosinolates, carotenoids, polyphenols, vitamin C, vitamin A and $\alpha$-tocopherol can be named from the herbal compositions found in this plant [17]. This plant is common in Europe and Asia. It has a harsh, sharp, piquant flavor. The plant growing in shallow and wetland can be grown $8-10$ $\mathrm{cm}$. Flowers are white. It is one of the most useful plants known in Eastern Azerbaijan. It is quite rich in C and A vitamins. In Azerbaijan climate conditions there is a warm and dry Temperament [18].

1) Against the cracks and allergies of the skin: Beating the Watercress, mixing with the honey and rubbing it on the skin.

2) Bronchitis treatment: $30 \mathrm{~g}$ Watercress is mixed with milk and drunk.

3) Disorders of liver and urinary tract disorders: Watercress Syrup is drunk every 6 hours with a glass of water. To make a Watercress Syrup, 650 grams of Watercress is mixed with half a kilo of powdered sugar and boiling at low temperature. If the mixture is left in its own state without heating, it becomes more 
useful paste.

4) Baldness treatment: $100 \mathrm{~g}$ Watercress mix with $25 \mathrm{gr}$ alcohol and hair is massaged.

5) Skin beautifier: Mix the Watercress with the honey and put it on the face as a mask.

6) Diabetes treatment: Watercress is consumed in raw milk.

7) Blood cleaner and agenda digestive system and liver: Watercress leaves are consumed in the spring.

8) Gout and rheumatism: Uses as poultice. Nasturtium officinale has been validated in the old Azerbaijan [1] [19].

\subsection{Mentha longifolia}

The Mint known locally as nane (Mentha longifolia L.) is a plant of Lamiaceae. Piperide oxide, piperitone, piperitenone, pulegone, $\mathrm{d}$-limonene, carvone, menton, $\beta$-caryophyllene, 1,8-cineol and menthol can be named from the herbal compositions found in this plant. It is Eurasian and Australian origin. It grows in moist areas. This perennial plant can last as long as $0.5-1$ meters. It likes the warm and dry climate. The leaves, which have a beautiful and pleasant smell, are consumed as dry and fresh. It is one of the most consumed medical plants of East Azerbaijan. The leaves are almost stalkless and often sparse or whitish. The flowers are white or violet [20] [21].

1) Pain relief, cold, flu, headache, digestive problems, low fever, sore throat and abdominal bloating, nausea and insomnia.

2) It is unhealthy and relieves stomach pain, anti-siccative, emollient, jaundice treatment, self [22].

\subsection{Pennyroyal}

The Pennyroyalknown locally as Yarpiz (Mentha pulegium L.) is a plant of Lamiaceae. Piperide oxide, piperitone, piperitenone, pulegone, $\mathrm{d}$-limonene, carvone, menton, $\beta$-caryofillene, 1,8-cineoleyl and menthol may be used from the herbal compositions found in this plant. The plant used as aroma, tea and spices is 10 to $50 \mathrm{~cm}$ high, petals are lilac, sharp-smelling, hazelnut-type, perennial, herbaceous, creepy or upright bodied. In Eastern Azerbaijan, the entire plant is consumed as an herbal drug [4].

1) Removing hiccups and anticonvulsants and calming nerves, treating diarrhea and intestinal diseases: Mint and thyme chew is helpful.

2) Anorexia treatment, anti-inflammatory cough and grip, sputum, anti-astringent, vasodilator, disinfectant and disinfectant, infusion tract for bloody diarrhea and treatment of neurological disorders, digestive disorders: Herbal tea.

3) Removing the thirst: Taking Mint with cucumber and white vinegar.

4) Treatment of colds, jaundice, headaches, digestive problems, fever, sore throat, nausea treatment, menstrual irritation and insomnia, body strengthening: Take a tablespoon of mint in a teapot with $80^{\circ} \mathrm{C}$ water. Take for 15 minutes. 
If you want to sweeten it, use honey or candy. Yarpuz in East Azerbaijan is proved by the local people [23].

\subsection{Cornelian Cherry}

The Cornelian cherry known locally as Zogal Axte (Cornus mas L.) is a plant of Cornaceae. Iron, calcium, vitamins, folic acid, anthocyanins, flavonoids such as E, B2, B1, C, and oxalic acid can be found in abundant amounts in this plant. It grows in Northern Europe, Azerbaijan, Georgia and Iran. It grows up to 5 - $8 \mathrm{~m}$ length. Leaves are dark green, both sides are hairy, veins are parallel, hairy along the veins. In February-March there are yellow colored small flowers, the fruit is red colored, elliptical shape. Cornelian cherry tree grows in dry soil, multiplies with seed. In our region, the fruit is used in the treatment of some cancer diseases [24].

1) Anti-Thirst: Cornelian cherry Syrup.

2) Treatment of diarrhea, fever and hemorrhoids, treatment of fever and multiple bowel incontinence: Cornelian cherry fruit.

3) Treatment of diarrhea: Flowers.

4) Fever: Herbal tea [22].

\subsection{Seaberry}

The Seaberry known locally as Aci İğde (Hippophae rhamnoides L.) is a plant of Elaeagnaceae. Among the herbal compositions found in this plant, $\beta$-sitosterol, 24-methyl enecycloartanol, squalene may be named. The plant in the bush form in Europe and western and Central Asia is a $10 \mathrm{~m}$ high, barbed tree. The young branches are as bright as silver, then puff as if they were rusted. The branches are $7 \mathrm{~cm}$. It is thorny. The leaves are knotty, with a dark green-gray top, six yellowish or white, bright as silver. The flowers are double sex. The color of the pomegranate juice is red or yellowish, the taste is sour. The fruit is shriveled, soft and crushed quickly. It grows in mountainous regions, on the shores of lakes and rivers, in sandy and stony areas. It is used as antioxidant [4] [25].

1) Treatment for headaches that do not have a specific symptom, fever, antidiabetic, bile duct hemorrhagic, hiccup, spasm and cardioprotective, gastro-intestinal tract, diarrhea and diarrhea: Seaberry fruit.

2) Fixing Osteoporosis: Seaberry Powdered 2 part and Roasted Soy Powder 1 part, Mix with honey, one spoon or 2 tablespoons a day with a glass of milk. This is a great breakfast for men and women.

3) Treatment of acute and chronic inflammation and retrograde therapy: Seaberry powder.

4) Osteoporosis and bone softening: A combination of Seaberry powder with roasted soy and mixing with a spoon with a glass of milk and a spoon of honey is the best medicine.

5) Strengthening the hair and increasing the growth of hair: Boil the Seaberry leaves in olive oil to make the leaves soft and crush, and use this oil to massage 
the head.

6) Treating joint pain and itchy skin. Increasing hair growth: An Seaberry, cooked in olive oil.

7) Treatment of arthritis and inflammation of the joints: Seaberry extract.

8) Wound healing: Flower.

9) Treatment of children's diarrhea: Seaberry decoction.

10) Treatment of acute and chronic inflammation: Seaberry powder.

11) Treatment of arthritis and anesthetized organs: Boil a Seaberry tree leaf in olive oil (first, keep the leaves in olive oil for 24 hours, then boil it in warm olive oil, to crumble if the contents are sealed in a glass and Boil in water to boil and squeeze it more). If it stains on the head, it will cause a high amount of hair.

12) The spiked nucleus hardens the root of the tooth and picks up against the bleeding. The skins are boiled and seasoned and tasted.

13) Treatment of Osteoporosis and Joint Pain: A number of freshly prepared fresh Seaberry, with skin, and meat, are pulverized by an electric mill. Take one to three tablespoons of powder in a glass of fresh milk and give it a sweet spoon of honey and serve as a meal or a snack [26].

14) Treatment for osteoporosis and joint pain: Bring some freshly prepared Seaberry with skin and meat and powder into powder by electric mill. Take one to three tablespoons of powder in a glass of fresh milk and give it a sweet spoon of honey and serve as a meal or a snack [27] [28] [29].

\subsection{Costmary}

The costmary known locally as Şahesparan (Tanacetum balsamita L.) is a plant of Asteraceae. Arvon (47.81\%), $\alpha$-thujone (12.56\%), germakren B (5.23\%), benzaldehyde (4.64\%), ethylbezene (3.96\%) and germacrene D (3.13\%) are among the healing compounds found in this plant. It is a fragrant plant that grows in many parts of Asia and Europe. The leaves that are formed by the joining of a few leaves attached to a stem are a plant with yellow flowers resembling a button. The length varies between 50 and $150 \mathrm{~cm}$ depending on the area where they grow. Tanacetum species are consumed as food by the larvae of some Lepidoptera species. However, the excessive consumption of flowers by humans is poisonous [30].

1) Marsiwan is widely consumed as tea or essence or as tea, to reduce pain and strengthen the stomach, to treat chest pain and cold and cough, to strengthen the stomach, to degress, mouth and digestive antiseptic, diuretic. It is used like bitter tea.

2) Removing oral pests: Condensed boiling water and chewing cream.

3) Headache Reduction: Smell it.

4) Increase the body's resistance to toxins: Eating Chesapeake seed [30] [31].

\subsection{Red Clover}

The Red Clover known locally as Keşe (Trifolium pratense L.) is a plant of Fa- 
baceae. Of the herbal compositions found in this plant, it can be called isoflavone. Red clover is a perennial herbaceous plant. The length is $50-80 \mathrm{~cm}$. It has a root system that goes $8-10$ meters deep under suitable conditions. For this reason, it has durabilities with the conditions of its homeland, the Middle East region, and it is resistant to drought. At the same time it is an important bait plant that is resistant to grazing. Leaves, flowers and seeds are used [32].

1) For prevention of heart disease, blood and body cleaner, cough and muscle aches, eliminate skin swelling, cure for asthma, cramping: 30 grams of dried plant is poured into a liter of boiling water for 5 minutes. A glass is used three times daily. 50 grams of the flower branches are boiled by pouring into the milk or the water and after cooling it is spread on the skin and paints in the form of an Ointment.

2) Artos and rheumatism treatment: Clove leaf is boiled in olive oil and applied to places where pain is present.

3) Wound treatment: Put on the wound in the form of a red triple Ointment.

4) Itch remover: Clover is crushed and applied onto the skin [33].

\subsection{White Horehound}

The White horehound known locally as Doşan topuği (Marrubium vulgare L.) is a plant of Lamiaceae. Among the herbal compositions found in this plant, Diterpenleri, sterols, flavonoids and phenylpropanoids can be named. In general, $60 \mathrm{~cm}$. Perennial, durable herbaceous plant can be picked up as much as possible. It is a dirty white color with four corners, feathers and branches separated. The edges of the heart-shaped, wrinkled-looking leaves on the body and stems are threaded, leafy wooly, covered with fur, and smelling. The plant opens its little white flowers on the leaf seats. The matured flowers give seeds with a tear-shaped, dark-brown, bright-looking appearance of $2 \mathrm{~mm}$ in length [33].

1) Spatula: 7 grams per $200 \mathrm{cc}$ of boiling water for 15 minutes. Drink 3 cups a day.

2) Stomach Strengthening: $3 \mathrm{~g}$ at $150 \mathrm{cc}$ boiling water for 15 minutes. After each meal, drink a cup.

3) Bronchial Disease: Drink 7 grams of this plant in $200 \mathrm{cc}$ of 15 -minute boiled herbal tea. Drink 3 cups a day.

4) Blood purifier, anemia, rectum, asthma: plant herbal tea.

5) Cheese: From this plant, 6 g per $200 \mathrm{cc}$ of boiled water is desired.

6) Bile marrow: Drink 10 grams of White horehound in $250 \mathrm{cc}$ of boiled water for 15 minutes, drinking 4 cups a day.

7) Sprained and ganglia wounds: Rinse wounds with herbal tea.

8) Cough relief: Mix the wheat bran in boiled water and then mix with whole plant or flower of White horehound, then apply a teaspoon a day for one week.

9) Tooth strength: The leaves of this plant are sprayed.

10) Healing the injury: Mix the crushed batch of this plant with salt. To heal the injury and the wound, the dog bites. 
11) Boost sight: Brew this plant with honey.

12) Relieve stomachache: Chew Leaves.

13) Neurological disorders: 8 grams pour in $250 \mathrm{cc}$ of boiling water for 15 minutes, and one cup per hour.

14) Obstructing lung and spleen: Herbal tea of plant.

15) Moist cough and sputum excretion: 2 grams of herbs and 2 grams of hyssop in $200 \mathrm{cc}$ boiling water for 15 minutes mix with sweet almond oil and drink for one week [34] [35].

\subsection{Ziziphora}

The Ziziphora known locally as Dağ nanəsi (Ziziphora clinopodioides L.) is a plant of Lamiaceae. Monoterpenoides and phenolic compounds such as thymol, pulegone, piperitenone and p-menthi-3-en-8-ol can be named from the herbal compositions found in this plant. Europe, Asia and Africa are also common. Upright, four-cornered body with pleasant smell. One year is a perennial herbaceous structure. The two-leafed and mutually-arranged leaves are short, long, deep and fuzzy with short stems, have strong smells. Flowers are two-lipped, purplish pink and bluish-colored. In dry places, on rocks, it is usually seen together with pine and juniper [17] [36].

1) Sputum and Biliary Remedy: Ziziphora tea, ziziphora tea making: Three cups of tea a day. Pour 2 to 3 grams of powder of the plant into 1 cup boiling water, then apply it well after 10 minutes. In the spring of the summer, local people collect the plant and add tea to the tea, as well as the use of powdered dried plant in this region and the properties of cacti are used to treat infertility in this area.

2) Physical strengthening: Ziziphora bath, 100 gr plant 3 liters boiling water is poured into the bathtub.

3) Diarrhea, abdominal pain, nose bleeding, stomach strengthening, Maltese Fever treatment: Boiled or brewed.

4) Rheumatism and bone softening: Boiled ziziphora.

5) Tonsilitis: Boiled gargle [37].

\subsection{Viper's Bugloss}

The Viper's bugloss known locally as Gözeban (Echium vulgare L.) is a plant of Boraginaceae. Mucilage, allantoin, phenyl propanoids, cinnamic acid and rosmarinic acid, citric, fumaric, malic, succinic acids, flavonoids can be named from the herbal compositions found in this plant. The viper is 30 to $50 \mathrm{~cm}$ in length and is a perennial plant. It is particularly common on the roadsides and leaves the fur. There are oval leaves. The flowers are lilac blueness and attract attention to beauty and beauty. Vigorous grass may remain flowering from May to October [4] [38].

1) Treatment of measles and scarring, inflammation and swelling of the kidneys, treatment of bronchitis, blood purifier, relaxing nerves, sweating, diuretic, 
kidney strengthening, relieving the common cold, eliminating cough: Breeding cattle.

2) Removing the swelling: Poultice of leaf.

\subsection{Clary}

The Clary known locally as Gara yarpağ (Salvia sclarea L.) is a plant of Lamiaceae. Linalool acetate (35.9\%), germakren D (13.3\%), linalool (12.8\%) and sclareol, antibacterial, antioxidant, antitumor, antidiabetic, antimicrobial, anxiolytic, sedative and anti-inflammatory are among the herbal compositions found in this plant. It is of Mediterranean origin. It is a two or perennial herbaceous plant that blooms in May-August; Rocky volcanic slopes up to $2000 \mathrm{~m}$ above sea level, mixed coniferous and leafy corals, and shale shrubs [39].

1) Analgesic, relaxing and reducing blood glucose, dyspepsia, pain and bloating, sore throat, tonsillectomy, mouth ulcers or gum disease: Herbal tea.

2) Arthralgia, rheumatism: Thickened boiled of this plant.

3) Relieve sore throat, anti-inflammatory and disinfectant: Leaves of this plant.

4) Removing dandruff, restoring hair color: Herbal tea from sage leaves. 20 grams of leaves in $500 \mathrm{ml}$ of water.

5) Eliminating night sweats and sweating caused by weakness: Herbal tea.

6) Sore throat, tonsillitis, mouth ulcers or gum disease: Gargle or rashes diluted with plant [8].

\subsection{Musk Willow}

The Musk willow known locally as Yörünce (Salix aegyptiaca L.) is a plant of Salicaceae. Bu bitki de bulunan şifalı bileşımlerinden, gallic asit, kafeik asit, myricetin, catechin, kuersetin, salicin, carvone, sitronelol, methyl eugenol, eugenol, n-tetradecane 4-methoxy-a-ethenone. Soğuk ve sslak mizaçli bitkidir ad edile bilir. Aklaşık 9 m'e kadar boylanabilen Çalı ve ya ağaç formundadır. The genital tract is a genital tract. Kulakçıklar böbrek biçiminde yarım yüreksi veya yarım daire biçiminde büyükür. Yapraklar eliptik, yumurtamsı (oval), ters yumurtamsı veya ters yumurtamsı-dikdörtgen ile ters yumurtamsı-mızrak biçimindedir [40].

1) Toning of the heart, reducing fever, strengthening the heart, relaxing and relieving pain and fatigue, laxative and boosting the heart and digestive system, appetite, augmenting the nervous system: Sweating, brewing and decoction of the leaf with honey nourishing the nerves. Preparation of pussy sweat in the early days of the spring is one of the traditions of the Azerbaijani families, especially the Orumiyeh families traditionally carried out, and this is a special tradition with certain rituals and sweatshops. Essential oil or pungent sweat is used in addition to the therapeutic properties of syrups.

2) Treatment of neurological diseases, depression, muscle aches and rheumatism diseases: Flower decoction.

3) Mustard musk is a laxative and amplifiers of the heart, nerves and sexual 
stimulants. This herbal drug strengthens the digestive system and increases appetite [37] [40].

\section{Final Conclusion}

The results of this study showed that the identification of local herbs and their medicinal properties can determine the potential of medicinal herbs, which will undoubtedly benefit for the better use of these medicinal plants. In addition, traditional use of plants in the area is widely used and is used more in the treatment of digestive diseases. Due to the traditional texture of the city and the wide reach of people in the traditional use of medicinal plants, further studies can help identify many of the properties of medicinal plants.

\section{References}

[1] Ozen, T. (2009) Investigation of Antioxidant Properties of Nasturtium officinale (Watercress) Leaf Extracts. Acta Poloniae Pharmaceutica ñ Drug Research, 66, 187-193.

[2] İmani, Y. (2014) Definition of Medicinal Plants. Eastern Azerbaijan, Tehran-Iran 1 st National Nature and Biology Congress, Center of Sustainable Development Transport Strategies, Iranian Support Organization. http://www.civilica.com/Paper-BSCONF01-BSCONF01_358.html

[3] Mostafavi, A. (2014) Medicinal Plants, with the Addition of Traditional Medicine to Azerbaijan. Yas Behesht Publication, Tahran, S 254.

[4] Mahdavi, M., Jouri, M.H., Mahzooni-Kachapi, S.S. and Sadeghi'hardoroodi, M. (2014) The Effects of Altitude on Productivity and Formative Components of Essential Oils of Artemisia absinthium L. (Iran). Bulletin of Environment, Pharmacology and Life Sciences, 3, 218-224.

[5] Sharopov, F.S., Sulaimonova, V.A. and Setzer, W.N. (2012) Composition of Essential Oil of Artemisia absinthium from Tajikistan. Records of Natural Products, 6, 127-134.

[6] Orava, A., Raalb, A., Arakb, E., Müüriseppa, M. and Kailas, T. (2006) Composition of the essential oil of Artemisia absinthium L. of different geographical origin. Proceedings of the Estonian Academy of Sciences Chemistry, 55, 155-165.

[7] Abad, M. J., Miguel Bedoya, L., Apaza, L. and Bermejo, P. (2012) The Artemisia L. Genus: A Review of Bioactive Essential Oils. Molecules, 17, 2542-2566. https://doi.org/10.3390/molecules17032542

[8] Asaadi, K., Moradi, P., Amini, K. and Habibi Lahiji, S. (2012) Investigating the Most Effective Compounds in Medicinal Plant of Sambucus nigra in Azerbaijan Region. Iranian Journal of Plant Physiology, 2, 485-488.

[9] Miraj, S. (2016) Chemical Composition and Pharmacological Effects of Sambucus nigra. Der Pharma Chemica, 8, 231-234.

[10] Bhat, H. M., Ahmad Bhat, K., Prabha, S. and Hamid, A. (2014) Antioxidant and Cytotoxic Activities of Achillea millefolium from Kashmir. Journal of Academia and Industrial Research, 2, 487-492.

[11] Lakshmi, T., Geetha, R.V., Roy, A. and Kumar, S. (2011) Yarrow (Achillea millefolium Linn.)-A Herbal Medicinal Plant with Broad Therapeutic Use-A Review. International Journal of Pharmaceutical Sciences Review and Research, 9, 136-141. 
[12] Senthil Kumar, K., Hassan Mustapha, M., Rajbhandari, A. and Ramakrishnan, R. (2011) Phytochemical and Pharmacological Studies on Achillea millefolium (L) Leaves. Research Journal of Pharmaceutical, Biological and Chemical Sciences, 2, 24-34.

[13] Bakhane, Y., Yadav, A.S., Bajaj, A., Sharma, A.K. and Raghuwanshi, D.K. (2014) Glycyrrhizaglabra L.: A Miracle Medicinal Herb. Indo American Journal of Pharmaceutical Research, 4.

[14] Roshan, A., Kumar, N. and Kumar, C. (2012) Phytochemical Constituent, Pharmacological Activities and Medicinal Used through the Millenia of Glycrrhiza glabra Linn: A Review. International Research Journal of Pharmacy, 3, 45-55.

[15] Bayati Zadeh, J., Moradi Kor, Z. and Karimi Goftar, M. (2013) Licorice (Glycyrrhiza glabra Linn) as a Valuable Medicinal Plant. International Journal of Advanced Biological and Biomedical Research, 1, 1281-1288.

[16] Damle, M. (2014) Glycyrrhiza glabra (Liquorice)—A Potent Medicinal Herb. International Journal of Herbal Medicine, 2, 132-136.

[17] Mazandarani, M. (2015) Ecological Study, Antioxidant and Antimicrobial Activity of Ziziphora clinopodioides Lam. in Golestan Province (Deraznoo Mountain), Iran. Crescent Journal of Medical and Biological Sciences, 2, 121-124.

[18] Hadjzadeh, M., Rajaei, Z., Moradi, R. and Ghorbani, A. (2015) Effects of Hydroalcoholic Extract of Watercress (Nasturtium officinale) Leaves on Serum Glucose and Lipid Levels in Diabetic Rats. Indian Journal of Physiology and Pharmacology, 59, 223-230.

[19] Karami, M., Nosrati, A., Naderi, M., Makhloogh, M. and Shahani, S. (2015) Protective Effects of Nasturtium officinale against Gamma-Irradiation-Induced Hepatotoxicity in C57 Mice. Research Journal of Pharmacognosy (RJP), 2, 19-25.

[20] Al-Okbi, S.Y., Fadel, H.H.M. and Mohamed, D.A. (2015) Phytochemical Constituents, Antioxidant and Anticancer Activity of Mentha citrata and Mentha longifolia. Research Journal of Pharmaceutical, Biological and Chemical Sciences, 6, 739-744.

[21] Abedi, R., Reza Golparvar, A. and Hadipanah, A. (2015) Identification of the Essential Oils Composition from Four Ecotypes of Mentha longifolia (L.) Huds. Growing Wild in Isfahan Province, Iran. J. BioSci. Biotechnol, 4, 117-121.

[22] Mikaili, P., Mojaverrostami, S., Moloudizargari, M. and Aghajanshakeri, S. (2014) Pharmacological and Therapeutic Effects of Mentha longifolia L. and Its Main Constituent, Menthol. Ancient Science of Life, 33, 129-139.

[23] Miraj, S. and Kiani, S. (2016) Study of Pharmacological Effect of Mentha pulegium: A Review. Der Pharmacia Lettre, 8, 242-245.

[24] Alavian, S.M., Banihabib, N., Es. Haghi, M. and Panahi, F. (2014) Protective Effect of Cornus Mas Fruits Extract on Serum Biomarkers in $\mathrm{CCl}_{4}$-Induced Hepatotoxicity in Male Rats. Hepatitis Monthly, 14, e10330.

[25] Asgarpanah, J. (2012) Phytopharmacology and Medicinal Properties of Salix Aegyptiaca L. African Journal of Biotechnology, 11, 7145-7150.

[26] Krejcarová, J., Straková, E., Suchý, P., Herzig, I. and Karásková, K. (2015) Sea Buckthorn (Hippophae rhamnoides L.) as a Potential Source of Nutraceutics and Its Therapeutic Possibilities-A Review. Acta Veterinaria Brno, 84, 257-268. https://doi.org/10.2754/avb201584030257

[27] Suryakumar, G. and Gupta, A. (2011) Medicinal and Therapeutic Potential of Sea Buckthorn (Hippophae rhamnoides L.). Journal of Ethnopharmacology, 138, 268-278. https://doi.org/10.1016/j.jep.2011.09.024 
[28] Patel, C.A., Divakar, K., Santani, D., Solanki, H.K. and Thakkar, J.H. (2011) Remedial Prospective of Hippophae rhamnoides Linn. (Sea Buckthorn). International Scholarly Research Network, 35, 1-14.

[29] Zeb, A. (2004) Important Therapeutic Uses of Sea Buckthorn (Hippophae): A Review. Journal of Biological Science, 4, 687-693. https://doi.org/10.3923/jbs.2004.687.693

[30] Hassanpouraghdam, M., Tabatabaie, S., Nazemiyeh, H., Vojodi, L., Aazami, M. and Mohajjel Shoja, A. (2008) Chrysanthemum balsamita (L.) Baill. A Forgotten Medicinal Plant. Medicine and Biology, 15, 119-124.

[31] Nobakht, A. and Moghaddam, M. (2013) The Effects of Different Levels of Costmary (Tanacetum balsamita) Medicinal Plant on Performance, Egg Traits and Blood Biochemical Parameters of Laying Hens. Iranian Journal of Applied Animal Science, 3, 307-312.

[32] Hu, H.H., Jing, C.Q., Liu, R., Li, W.D. and Feng, H.G. (2015) Cloning and Transformation Analysis of Isoflavone Synthase Gene into Minshan Trifolium pratense. Genetics and Molecular Research, 14, 9291-9297.

https://doi.org/10.4238/2015.August.10.9

[33] Said-Al Ahl, H.A.H., Gendy, S.H., Mahmoud, A. and Mohamed, F.Y. (2015) Essential Oil Composition of Marrubium vulgare L. Cultivated in Egypt. International Journal of Plant Science and Ecology, 1, 138-141.

[34] Vlaisavljevic, S., Kaurinovic, B., Popovic, M., Djurendic-Brenesel, M., Vasiljevic, B., Cvetkovic, D. and Vasiljevic, S. (2014) Trifolium pratense L. as a Potential Natural Antioxidant. Molecules, 19, 713-725. https://doi.org/10.3390/molecules19010713

[35] Bokaeian, M., Saboori, E., Saeidi, S., Ali Niazi, A., Amini-Borojeni, N., Khaje, H. and Bazi, S. (2013) Phytochemical Analysis, Antibacterial Activity of Marrubium vulgare L. against Staphylococcus Aureus In Vitro. Zahedan Journal of Research in Medical Sciences, 16, 60-64.

[36] Niazmand, S., Derakhshan, M., Erfanian Ahmadpour, M. and Hosaeni, K. (2010) The Inhibitory Effect of Ziziphora clinopodioides Lam. on Gastric acid Output at Basal, Vagotomized and Vagal Stimulated Conditions in Rat. Iranian Journal of Basic Medical Sciences, 13, 36-39.

[37] Anonymous (2013) Assessment Report on Marrubium vulgare L., Herba. Committee on Herbal Medicinal Products (HMPC).

[38] Zhang, X., Ding, W., Li, J., Liu, F., Zhoud, X. and Tian, S. (2015) Multi-Elemental Analysis of Ziziphora clinopodioides from Different Regions, Periods and Parts Using Atomic Absorption Spectrometry and Chemometric Approaches. Revista Brasileira de Farmacognosia, 25, 465-472. https://doi.org/10.1016/j.bjp.2015.07.021

[39] Moallem, S.A., Hosseinzadeh, H. and Ghoncheh, F. (2007) Evaluation of Antidepressant Effects of Aerial Parts of Echium vulgare on Mice. Iranian Journal of Basic Medical Sciences, 10, 189-196.

[40] Cui, H., Zhang, X., Zhou, H., Zhao, C. and Lin, L. (2015) Antimicrobial Activity and Mechanisms of Salvia sclarea Essential Oil. Botanical Studies, 56, 16.

https://doi.org/10.1186/s40529-015-0096-4 